\title{
A Case of Thyroid Insular Carcinoma with Multiple Bone Metastases Presenting as Pyriform Sinus Mass
}

\author{
Jeon Ha Choi ${ }^{1}$, Seok Jung Hong ${ }^{1}$, Mi Ji Lee ${ }^{2}$, and Seung Woo Kim ${ }^{1}$ \\ ${ }^{1}$ Departments of Otolaryngology-Head and Neck Surgery, ${ }^{2}$ Pathology, Veterans Health Service Medical Center, Seoul, Korea
}

\section{이상동 종물 양상의 다발성 골전이를 동반한 갑상선 섬 암종 1예}

최전하 ${ }^{1} \cdot$ 홍석정 $^{1} \cdot$ 이미지 ${ }^{2} \cdot$ 김승우 $^{1}$

중앙보훈병원 이비인후과, ${ }^{1}$ 병리과 ${ }^{2}$

Received March 7, 2016

Revised April 15,2016

Accepted April 19, 2016

Address for correspondence

Seung Woo Kim, MD

Department of Otolaryngology-

Head and Neck Surgery,

Veterans Health Service

Medical Center,

53 Jinhwangdo-ro 61-gil,

Gangdong-gu,

Seoul 05368, Korea

Tel $+82-2-2225-1384$

Fax $+82-2-2225-1385$

E-mail entzzang1020@hanmail.net
Thyroid insular carcinoma (TIC, poorly differentiated thyroid carcinoma) is derived from thyroid follicular cells and known to show pathophysiologic behaviors intermediate between well-differentiated and undifferentiated types of thyroid carcinoma. The estimated incidence of TIC is from $0.4 \%$ to $5 \%$ of all thyroid cancers and is rare in Asians. Moreover, the multiple bone metastases in TIC have been rarely reported so far. Clinically, there are two pathways that thyroid cancer is presented, either as a parapharyngeal or retropharyngeal mass. For the first pathway, the mass is located on the thyroid upper pole and it grows toward the anatomical defect of posterior aspect of inferior pharyngeal constrictor. The second pathway involves a pharynx directly compressed by the mass from outside to inside of inferior pharyngeal constrictor. A 66-year-old man who had a thyroid mass revealed important clinical findings: a right pyriform sinus mass from laryngoscopy and multiple bone metastases from radiology. We performed subtotal thyroidectomy with central neck dissection. The mass was confirmed as TIC from follicular thyroid carcinoma. The patient received radiation and radioactive iodine therapy, and bcause of a remnant thyroid mass, he was observed closely. We herein report a rare, unique case of TIC with a review of literatures.

Korean J Otorhinolaryngol-Head Neck Surg 2016;59(7):542-6

Key Words Multiple bone metastases · Pyriform sinus mass · Thyroid insular carcinoma.

\section{서 론}

갑상샘에 발생하는 섬 암종 또는 인슐라 암종(insular carcinoma)은 여포세포에서 유래하여 분화성 갑상샘 암과 역형 성 암의 중간 정도의 병태 생리를 보이며 예후가 불량한 것으 로 알려져 있다. 전체 갑상샘 암종의 $0.4 \sim 5 \%$ 정도를 차지하 며, 아시아 인종에서는 더욱 드물다. ${ }^{2)}$ 섬 암종에서 골로 원격 전이가 일어날 수 있으며, 흉골로 전이한 보고는 있었지만, ${ }^{3}$ 흥 골, 장골 및 척추 등으로 다발성 전이를 한 경우는 보고된 적 이 없다.

임상적으로 갑상샘 암이 측인두 또는 후인두 종물로 나타 나는 경우는 두 가지 해부학적 기전이 있다고 알려져 있다. 종
물이 갑상샘 상극에 위치하면서 그 성장하는 방향이 하인두 수축근 후방의 해부학적 결손 부위이거나, 종물이 인두를 하 인두 수측근의 외측에서 내측 방향으로 심하게 압박하는 경 우 등이다. ${ }^{45}$

술 전에 다발성 골전이를 동반한 여포성 암종으로 의심되었 던 66세 남자 환자에게 갑상선 아전적출술 및 중심 림프절 절 제술을 시행하였고, 조직병리검사에서 여포상 암종에서 유래 한 섬암종으로 진단되었다. 술 후 치료로 방사선 및 고농도 요 오드 동위원소 치료를 시행하였고, 현재 질병이 있는 상태에 서 더 이상 진행 없이 추적 관찰 중이다. 이상동 종물 양상의 다발성 골 전이를 동반한 섬 암종의 드문 증례를 문헌 고찰 과 함께 보고하고자 한다. 


\section{증 례}

66세 남자 환자가 5년 전 양측 갑상선 결절 진단 후 내분비 내과 추적 관찰 중 연하장애, 경부 이물감 및 요통 등을 호소 하며 본과로 내원하였다. 신체 검사상 전경부의 좌하방에 $2 \times$ $3 \mathrm{~cm}$ 크기의 비교적 부드러운 성상의 종물이 촉지되었고, 우 측 갑상선 부위는 저명하게 돌출되어 있지 않았다. 흥골 병의 우측으로 비교적 단단하고, 가동성이 떨어지는 $3 \times 4 \mathrm{~cm}$ 크기 의 종물이 관찰되었다(Fig. 1A). 경성 후두 내시경검사에서 우측 이상동에 점막하 종물이 관찰되었으나(Fig. $1 \mathrm{~B})$, 성대 움
직임은 정상이었다. 경부 초음파 소견은 좌측 갑상샘을 가득 채우는 석회화를 동반한 $3 \times 4 \mathrm{~cm}$ 크기의 저에코 음영의 종물 과 우측 갑상샘 상부에 $2 \times 3 \mathrm{~cm}$ 크기의 불규칙한 경계를 보이 며, 갑상연골 침범이 의심되는 저에코 음영의 종물 소견이었다 (Fig. 2A and B). 초음파 유도하 세침흡입검사에서 우측 갑상 샘 종물은 베데스다 분류 IV, 좌측은 III 등으로 보고되었고, 경부 전산화단층촬영에서 $2 \times 3 \mathrm{~cm}$ 크기의 우측 갑상연골 침 범이 의심되는 우측 이상동내 연조직 종물, 좌측 갑상샘에 $3 \times$ $4 \mathrm{~cm}$ 의 불균질한 음영의 종물과 $4 \times 4 \mathrm{~cm}$ 크기의 우측 흥골 을 침범한 연조직 종물 소견이 관찰되었다(Fig. $2 \mathrm{C}, \mathrm{D}$, and $\mathrm{E}$ ).

Fig. 1. The clinical photo and laryngoscopic findings. The external photograph shows protruding mass at left lower midline neck (arrowheads) and right sternal mass (arrows) (A). The rigid laryngoscopy shows submucosal mass in right pyriform sinus (arrowheads) (B).
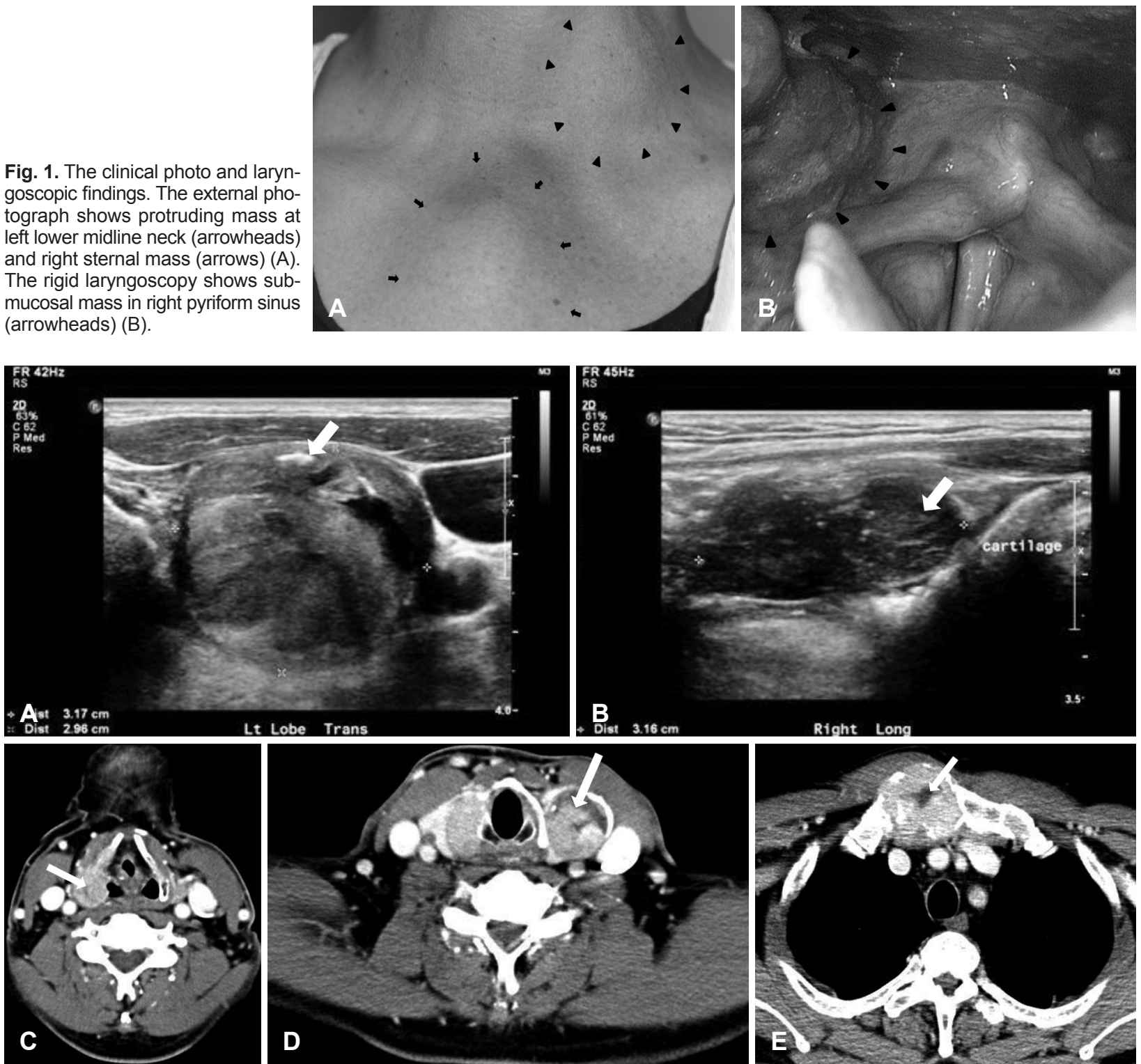

Fig. 2. Radiologic findings. The thyroid ultrasonography show a macro-calcification (white arrow) containing $3 \times 4 \mathrm{~cm}$ sized mass in left thyroid gland $(A)$ and $2 \times 3 \mathrm{~cm}$ sized hypoechoic mass with ill-defined margin in right thyroid gland extending toward upper pole (white arrow) (B). The preoperative enhanced axial neck CT scans show $2 \times 3 \mathrm{~cm}$ sized enhanced soft tissue density invading the thyroid cartilage and pyriform sinus (white arrow) (C), $3 \times 4 \mathrm{~cm}$ sized heterogenous mass in left thyroid (white arrow) (D) and $4 \times 4 \mathrm{~cm}$ sized osteolytic soft tissue lesion in right side manubrium of sternum (white arrow) (E). 
원격전이를 평가하기 위하여 골 스캔과 양전자 방출단층촬 영을 시행하였다. 전자에서는 우측 흥골에 양전자 결손 부위 와 함께 병변의 경계를 따라 강한 방사능 섭취소견이 관찰되 었고, 4번 요추와 장골에서도 경미한 섭취 증가소견이었으며 (Fig. 3A), 양전자 방출단층촬영에서도 다른 검사들에 부합 되는 소견을 보였다(Fig. $3 \mathrm{~B}, \mathrm{C}$, and D). 갑상샘 기능 검사에서
는 혈청 티로글로불린 항원만 $20767.0 \mathrm{ng} / \mathrm{mL}(0$ 40)로 매우 증가되어 있고, 나머지는 정상범위였다.

이상의 결과를 통해 다발성 골전이를 동반한 여포상 갑상 샘암으로 술 전 진단하였다. 수술 계획은 우측 갑상샘의 상부 종물은 이상동 외측 점막과 잘 박리되면 한 덩어리로 제거하 고, 만약 심한 유착으로 이상동 점막과 종물의 박리가 불가능
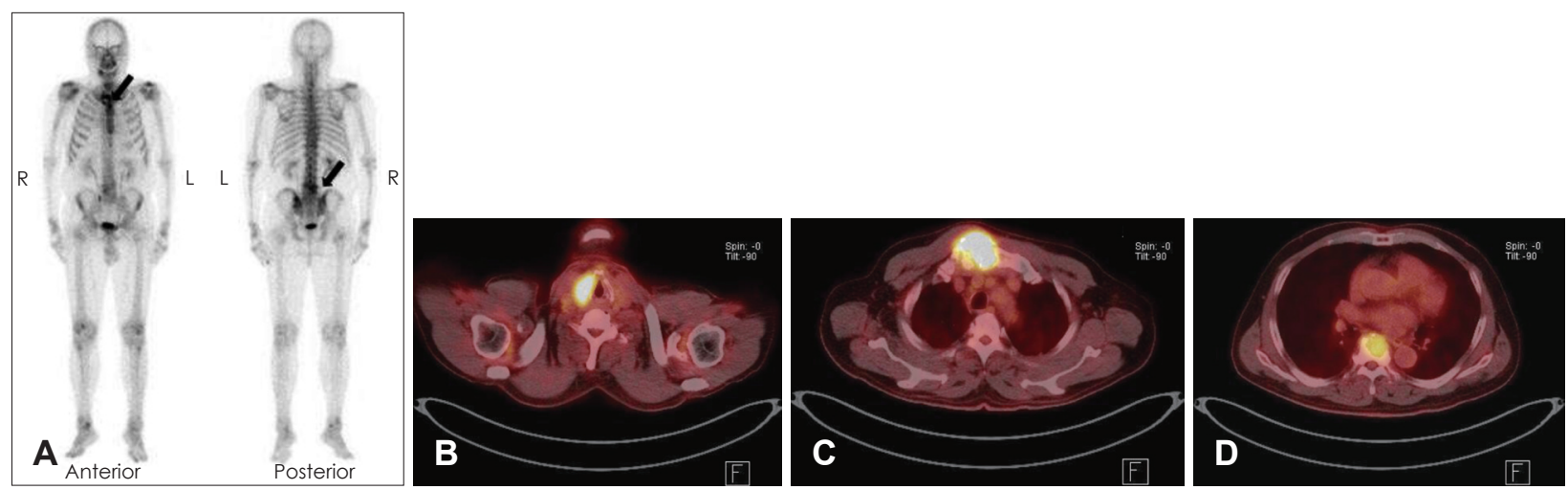

Fig. 3. Nuclear imaging findings. The Tc-99m HDP whole body bone scan show the cold defect with surrounding increased uptake in the sternum, 4th lumbar spine and left ileum (black arrows) (A). The ${ }^{18} \mathrm{~F}-\mathrm{FDG}$ positron emission computed tomography scans show hypermetabolic lesions on right thyroid cartilage (B), right side sternum (C) and 4th lumbar spine (D) (standard uptake value max=10.4). Tc-99m HDP: hydroxymethane diphosphonate.

Fig. 4. The intraoperative photo shows severe adhesion between right thyroid upper pole and lateral wall of pyriform sinus (white arrow) (A). The gross photograph shows left thyroid gland was mostly replaced by the mass (white arrow) (B).
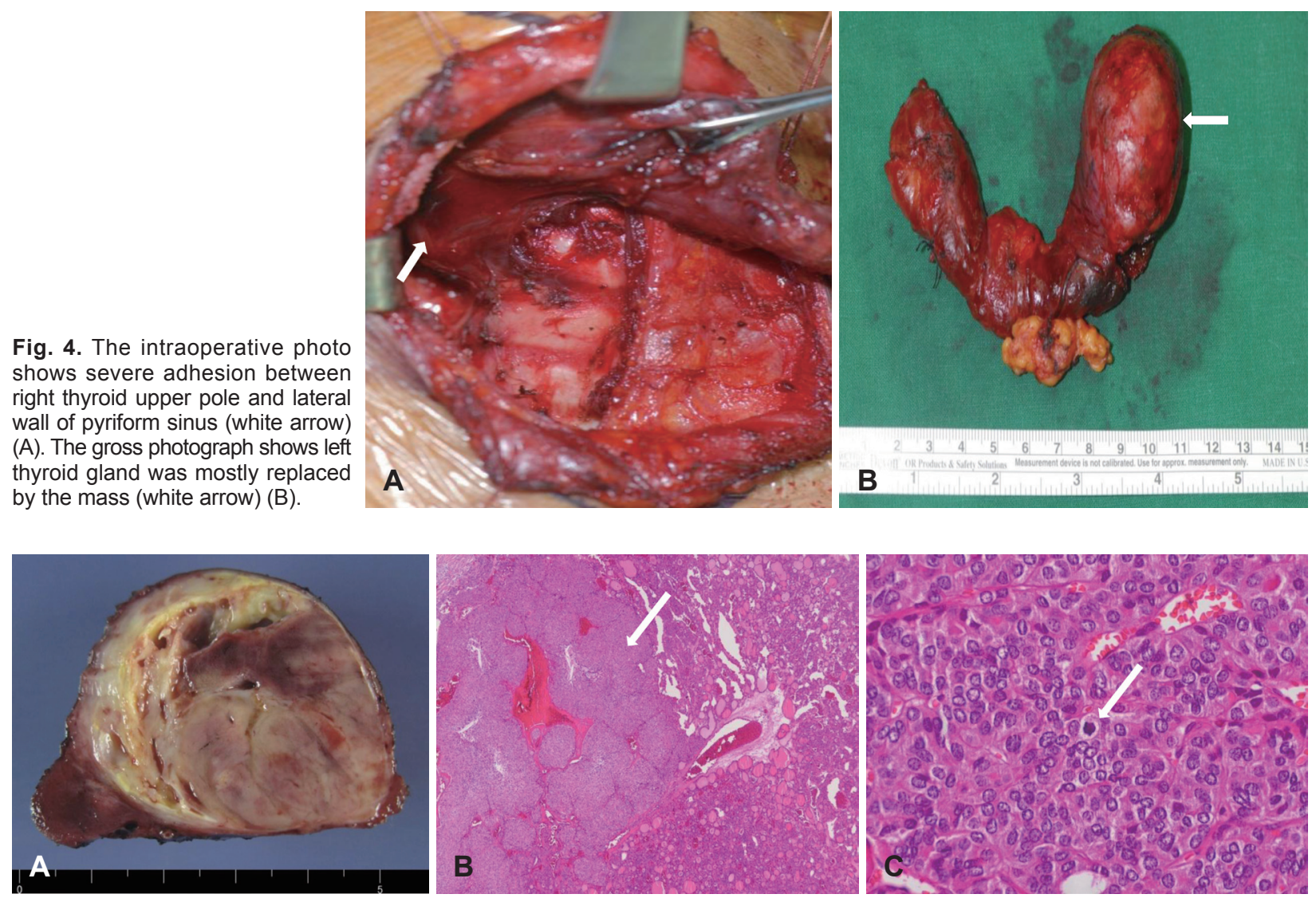

Fig. 5. The pathologic findings. The cut surface of left thyroid gland shows gray white, firm with fibrous thick capsule and calcification and perithyroidal soft tissue invasion (A). It shows characteristic cellular nests (insulae) of small uniform tumor cells in follicular cells (white arrow) $(H \& E, \times 200)(B)$. The mitotic nuclear with indistinct nucleoli is observed (white arrow) $(H \& E, \times 400)(C)$. 
하여 자유 피판술이 필요할 경우에는 환자의 종교적인 이유 와 다발성 골 전이 병변의 완전한 절제 불가능 등의 이유로 유착 부위의 종물은 남기기로 계획을 하였다. 수술 소견은 먼저 좌측 갑상선과 중심 림프절을 제거하고, 우측 갑상선을 제거하였다. 좌측 갑상선은 주변 구조물과 비교적 용이하게 박리되었으나, 우측 상부 갑상샘의 종물은 하부 인두 괄약근 및 이상동의 외측 점막과 심한 유착이 관찰되어 조직검사를 위해서 일부 종물만 제거한 후 수술을 종료했다(Fig. 4). 술 후 애성 및 저칼슘증 등의 합병증은 없었으며, 최종 조직 검 사에서 우측은 여포상 갑상샘 암종, 좌측은 피막, 림프혈관, 갑상샘 주변 연조직을 침범하고 있는 여포상 암종에서 유래 한 섬 암종으로 진단되었다(Fig. 5). 우측 기관주변 림프절로 1 개의 전이가 있어서, 최종적으로 $\mathrm{pT}_{3} \mathrm{~N}_{1 \mathrm{a}} \mathrm{M}_{1}$ 으로 평가되었다. 술 후 치료로 흥골과 척추 전이에 대하여 $20 \mathrm{~Gy} / 5 \mathrm{fx}$ 의 외부 방사선 조사와 $180 \mathrm{mCi}$ 의 고농도 방사능 요오드 동위원소 치료를 시행하였고, 현재 술 후 7개월 경과하였고, 더 이상 질 병의 진행 없는 상태로 추적 관찰 중이다.

\section{고 찰}

저분화성 갑상샘 암종 즉, 섬 암종이란 여포상 및 유두상 암종과는 상이한 조직학적 형태를 취하며 임상 및 병리학적 으로 분화성 암종과 악성도가 높은 티로글로불린 음성의 역 형성 암종의 중간에 위치하는 암종으로 정의된다. ${ }^{1)}$ 섬 암종 은 전체 갑상샘 암종 중에서 약 $0.4 \sim 5 \%$ 를 차지하고 발병 평 균 연령이 49세 이상이며, 림프절 전이는 $40 \%$ 이상, 원격전 이는 50\% 이상으로 5년 생존율은 65 85\% 정도이다. ${ }^{6}$ 예후 인자로는 연령, 종양의 크기, 림프절 전이, 원격전이, 종물의 괴사, 유사분열의 정도 등이 보고되었다.) Turin의 조직학적 진단기준은 고형성, 기둥모양, 혹은 섬모양의 성장 형태를 보
이고, 유두상 암종에서의 세포핵 특징이 관찰되지 않으며, 나 선형 핵, 10 배의 고배율 시야에서 3개 이상의 유사분열상 및 종양의 괴사 등 세 가지 가운데 하나 이상의 소견이 관찰되어 야 한다. ${ }^{8)} \mathrm{Lee}$ 등 ${ }^{9}$ 에 의하면 술 후 섬 암종으로 진단된 9예의 환자의 술 전 세침흡인검사 결과는 4 예는 여포상 종양, 4 예는 갑상선 선종 그리고 1 예는 수질암종으로 보고되어, 진단 정확 도가 낮다고 하였다. 본 증례에서도 술 전 세침흡인검사에서 베데스타 분류 III, IV로 보고되어, 확진을 위해서 반드시 술 후 조직검사가 필요하였다.

본 증례의 환자는 연하장애와 이물감을 주소로 본과에 내 원하였고, 갑상샘 질환의 병력이 없었다면, 후두 내시경 소견 에서의 이상동 종물을 다른 질환과 연관지을 수도 있었다. 서 론에서 언급한 기전에 의하여 갑상선 종물이 후인두 및 하인 두의 점막하 종물로 나타날 수 있다. ${ }^{4.5)}$ 현재까지 갑상샘 종물 이 후인두로 직접 침범한 경우는 Kang 등이이 보고한 유두상 암종의 증례 이외에는 보고가 없었다. 후인두로의 직접 침범 은 하인두 수축근의 후방 부위에 있는 해부학적 결손 부위를 통해 일어나며, 이런 경우 영상학적으로 후인두 림프절 전이 보다 하방에서 병변이 관찰된다.) 이런 경우 본 증례처럼 갑상 선 상극의 종물과 연결되어 있는지를 잘 관찰해야 한다. 수 술 시 종물의 압박에 의해서 이상동의 외측과 후면의 점막이 신장되어 있어서 박리 시 이곳의 열상 및 결손이 생기지 않도 록 주의해야 하며, 반회후두 신경이 후두로 들어가는 갑상윤 상 관절 주변과 상후두 신경의 외측 분지의 주행로에 종물이 위치하므로 신경 손상에 매우 유의해야 한다.,5)

섬 암종은 국소 및 지역 재발 그리고 원격전이의 빈도가 높 아서, 분화성 갑상샘암보다 더 공격적인 암으로 생각되며, 가 장 흔한 원격전이는 폐와 골이다. ${ }^{10}$ 그러나, 섬 암종이 본 증례 처럼 다발성으로 골을 침범한 보고는 없었으며, Koh 등히이 단발성으로 흥골을 침범한 증례를 보고한 것이 있다. 예후와

Table 1. Summary of previous case reports on the thyroid insular carcinoma in Korea, including our case

\begin{tabular}{|c|c|c|c|c|c|c|c|c|c|}
\hline Case & Author & Age & Sex & Local invasion & Distant metastasis & Treatment & RAl & RT & Follow-up \\
\hline 1 & Chung, et al. ${ }^{15)}$ & 39 & $\mathrm{~F}$ & No & No & TT with MRND & $150 \mathrm{mCi}$ & No & NED, $54 \mathrm{M}$ \\
\hline 2 & Chung, et al. ${ }^{15)}$ & 53 & M & Trachea, SH & Lung, brain & TT with ACND & $200 \mathrm{mCi}$ & 30 Gy & $\mathrm{DOD}, 51 \mathrm{M}$ \\
\hline 3 & Chung, et al. ${ }^{15)}$ & 35 & $\mathrm{~F}$ & Yes & No & TT with ACND & Yes & No & NED, $6 \mathrm{M}$ \\
\hline 4 & Chung, et al. ${ }^{15)}$ & 51 & $\mathrm{~F}$ & SH, IJV, trachea & No & TT with ACND & $180 \mathrm{mCi}$ & No & NA \\
\hline 5 & Chung, et al. ${ }^{15)}$ & 39 & $\mathrm{~F}$ & Mediastinum & no & Right MRND & No & No & NA \\
\hline 6 & Koh, et al. ${ }^{3)}$ & 75 & $\mathrm{~F}$ & Mediastinum & Sternum & $\begin{array}{l}\text { TT with ACND, } \\
\text { sternotomy, } \\
\text { LND, MLND }\end{array}$ & $180 \mathrm{mCi}$ & No & NED, $22 \mathrm{M}$ \\
\hline 7 & Kim, et al. ${ }^{16)}$ & 37 & M & Mediastinum & No & TT with ACND, MLND & $150 \mathrm{mCi}$ & No & NED, $12 \mathrm{M}$ \\
\hline 8 & Present case & 66 & M & Pyriform sinus & Sternum, spine etc. & ST with ACND & $180 \mathrm{mCi}$ & $20 \mathrm{~Gy}$ & AWD, $7 \mathrm{M}$ \\
\hline
\end{tabular}

RAI: radioactive iodine, RT: radiation therapy, TT: total thyroidectomy, MRND: modified radical neck dissection, NED: no evidence of disease, M: months, SH: sternohyoid, IJV: internal jugular vein, ACND: anterior compartment neck dissection, DOD: died of disease, NA: not available, recent case, LND: lateral neck dissection, MLND: mediastinal lymph node dissection, ST: subtotal thyroidectomy, AWD: alive with disease 
치료에 대해서는 발생빈도가 매우 낮아 대규모 연구가 부족하 여 현재까지도 많은 이견이 있다. 여포성 암종이 공존했던 본 증례에서와 같이 섬 암종과 공존하는 고분화 암종이나 역형 성 암종의 비율도 예후에 영향을 미치는 인자로 생각되며, ${ }^{3)}$ Volante 등 ${ }^{11)}$ 에 의하면 45세 이상, 괴사의 존재, 유사분열이 높 은 경우 $(>3 / 10 \mathrm{HPF})$ 에 예후가 불량하다고 보고하였다.

표준화된 치료는 없지만 섬 암종의 기본치료는 수술이다. 수술의 범위에 대해서는 논란의 여지가 있으나, 재발이 분화 성 갑상샘 암에 비하여 높고, 술 후 혈청 티로글로블린을 이 용한 추적 관찰을 위해서 재발률이 낮은 갑상샘 전절제술이 권장되며, 약 40 80\%의 림프절 전이율을 보이므로 중심 림 프절 절제술을 시행하는 것이 권장된다. ${ }^{2,12)}$ 본 증례에서도 다 발성 골전이가 없었다면, 술 전에 자유 피판술을 준비하고, 갑상선 전절제술과 중심 림프절 제거술을 계획하였을 것으 로 사료된다.

저분화 갑상샘 암종은 75 85\%의 방사성 요오드 섭취율 을 가지고 있고, 림프절과 원격전이 빈도가 높으므로 방사성 요오드 치료를 적극적으로 고려해야 한다. ${ }^{12)}$ 분화성 암종에 서는 수술 시 육안적 또는 절제연의 잔존암, 병리학적 $\mathrm{T} 4$, $\mathrm{N} 1 \mathrm{~b}$ 병기, 전이된 림프절의 크기가 $2 \mathrm{~cm}$ 이상일 때 방사선 치 료를 시행한 경우 국소재발률이 낮다는 보고가 있으나, ${ }^{12)}$ 저 분화 갑상샘 암종에서의 방사선 치료의 효과에 대한 연구는 없다. 그러나, 분화암에 비하여 더 침습적인 양상을 보이는 섬암종에서도 육안적 잔존암, 미세한 갑상선외 침범, 림프절 의 피막외 침범, 광범위한 림프절 전이 등이 있는 경우 방사선 치료를 고려할 수 있다는 보고도 있다. ${ }^{13)}$ 갑상샘 암종의 단발 성 골전이는 원발암의 종류와 상관 없이 수술이 가능하면 골전이 부위의 절제술이 추천되는데, 이는 골전이 부위의 절 제연 및 다른 전이 부위에 대한 방사성 요오드 치료의 효과 를 높일 수 있기 때문이다. ${ }^{14)}$ 본 증례에서는 섬 암종의 다발성 골전이로 인해 모든 부위의 외과적 절제가 불가능하여 우측 갑상샘 상부의 종물은 조직검사 목적으로 일부 조직만을 절 제하였고, 여포상 암종으로 진단되었다. 하지만, 본 증례의 경 우는 일반적인 여포상 암종보다 심한 국소 침범과 원격전이 가 존재한 경우여서, 만약 우측 갑상샘 종물을 전부 적출하 였다면, 좌측 갑상샘처럼 섬 암종의 공존 가능성을 예상할 수 있다. 국내에서 증례로 별도 보고되었던 7예의 섬 암종과 본 증례에 관하여, 표로 정리하였다(Table 1). ${ }^{15,16)}$

저자들은 본 증례를 통해서 연하곤란을 호소하는 이상동
종물을 가진 환자에서 갑상샘 암에 의한 직접침범을 고려해 야 한다는 교훈과 섬 암종의 다기관 공동 연구를 통하여 표 준 진단 및 치료에 관한 연구의 필요성을 절감하였다.

\section{REFERENCES}

1) Carcangiu ML, Zampi G, Rosai J. Poorly differentiated (“insular”) thyroid carcinoma. A reinterpretation of Langhans' "wuchernde Struma". Am J Surg Pathol 1984;8(9):655-68.

2) Rodriguez JM, Parrilla P, Moreno A, Sola J, Pinero A, Ortiz S, et al. Insular carcinoma: an infrequent subtype of thyroid cancer. J Am Coll Surg 1998;187(5):503-8.

3) Koh YW, Lee SW, Lee JD, Kim HJ, Kim HK. A case of advanced thyroid insular carcinoma with invasion of the sternum. Korean J Head Neck Oncol 2005;21(2):178-82.

4) Kang JH, Yang SC, Kim CD, Kim SW. Thyroid papillary carcinoma presenting as posterior pharyngeal mass: a case report. Korean $\mathrm{J}$ Head Neck Oncol 2010;26(2):221-4.

5) Lombardi D, Nicolai P, Antonelli AR, Maroldi R, Farina D, Shaha AR. Parapharyngeal lymph node metastasis: an unusual presentation of papillary thyroid carcinoma. Head Neck 2004;26(2):190-6.

6) Wreesmann VB, Ghossein RA, Patel SG, Harris CP, Schnaser EA, Shaha AR, et al. Genome-wide appraisal of thyroid cancer progression. Am J Pathol 2002;161(5):1549-56.

7) Volante M, Cavallo GP, Papotti M. Prognostic factors of clinical interest in poorly differentiated carcinomas of the thyroid. Endocr Pathol 2004;15(4):313-7.

8) Volante M, Collini P, Nikiforov YE, Sakamoto A, Kakudo K, Katoh $\mathrm{R}$, et al. Poorly differentiated thyroid carcinoma: the Turin proposal for the use of uniform diagnostic criteria and an algorithmic diagnostic approach. Am J Surg Pathol 2007;31(8):1256-64.

9) Lee TW, Chung KW, Chang MC, Yoo SH, Noh DY, Youn YK, et al. Clinicopathologic features of poorly differentiated (Insular) carcinoma of thyroid. J Korean Surg Soc 2003;64(2):121-6.

10) Bongiovanni M, Sadow PM, Faquin WC. Poorly differentiated thyroid carcinoma: a cytologic-histologic review. Adv Anat Pathol 2009;16 (5):283-9.

11) Volante M, Landolfi S, Chiusa L, Palestini N, Motta M, Codegone A, et al. Poorly differentiated carcinomas of the thyroid with trabecular, insular, and solid patterns: a clinicopathologic study of 183 patients. Cancer 2004;100(5):950-7.

12) Patel KN, Shaha AR. Poorly differentiated and anaplastic thyroid cancer. Cancer Control 2006;13(2):119-28.

13) Sanders EM Jr, LiVolsi VA, Brierley J, Shin J, Randolph GW. An evidence-based review of poorly differentiated thyroid cancer. World J Surg 2007;31(5):934-45.

14) Maheshwari YK, Hill CS Jr, Haynie TP 3rd, Hickey RC, Samaan NA. 131I therapy in differentiated thyroid carcinoma: M. D. Anderson Hospital experience. Cancer 1981;47(4):664-71.

15) Chung WY, Shim JY, Park CS. Well differentiated thyroid carcinoma with insular component. Korean J Head Neck Oncol 1997;13(1):7480.

16) Kim JW, Cho BH, Han GS, Kim YM. Insular carcinoma of the thyroid with jugular vein invasion. Korean J Otolaryngol-Head Neck Surg 2006;49(4):459-63. 